\title{
Water Permeability Characteristics of Normal Strength Concrete Made from Crushed Clay Bricks as Coarse Aggregate
}

\author{
Syed Ishtiaq Ahmad and Mohammad Anwar Hossain \\ Department of Civil Engineering, Bangladesh University of Engineering and Technology, Dhaka, Bangladesh \\ Correspondence should be addressed to Syed Ishtiaq Ahmad; siahmad@ce.buet.ac.bd
}

Received 13 July 2017; Revised 6 October 2017; Accepted 19 October 2017; Published 6 November 2017

Academic Editor: Kaveh Edalati

Copyright ( 2017 Syed Ishtiaq Ahmad and Mohammad Anwar Hossain. This is an open access article distributed under the Creative Commons Attribution License, which permits unrestricted use, distribution, and reproduction in any medium, provided the original work is properly cited.

\begin{abstract}
Water permeability characteristic of concrete made from crushed clay bricks as coarse aggregate is investigated and compared with concrete made from natural stone aggregate. For this, six different brick and five different natural stone samples were selected. Crushing strength of brick samples and water absorption of aggregate produced from them were also measured. Concrete samples of three different compressive strengths were prepared as per ACI mix design method from each of these aggregate samples. Compressive strength of concrete that could be achieved with brick aggregate varied between 19 and $28 \mathrm{MPa}$, whereas, for stone aggregate, compressive strength varied between 24 and $46 \mathrm{MPa}$. These samples were then tested for water permeability using the AT 315 machine as per EN 12390-8: "Depth of Penetration of Water under Pressure." Experimental results and subsequent analysis indicate that water permeability of brick aggregate concrete is $225 \%$ to $550 \%$ higher than that of concrete made from natural stone aggregate of identical compressive strength. Water permeability was found to be directly related to compressive strength, water absorption, and porosity of hardened concrete. It was also observed that water permeability of concrete is influenced by water absorption of brick aggregate and crushing strength of brick.
\end{abstract}

\section{Introduction}

Concrete is the main ingredient in ever growing construction industry of Bangladesh. As natural stone is in short supply and hence expensive, crushed burnt clay bricks are extensively used as an economic alternative coarse aggregate in preparation of concrete in Bangladesh for construction of midrise residential and factory buildings, rigid pavements, and small and medium span bridges and culverts [1]. Properties of brick aggregate vary appreciably from natural stone aggregate in the context of strength, toughness, and other related indices [2]. Since coarse aggregate occupies a large share of concrete volume, therefore, it is presumable that the properties of concrete made from brick aggregate will vary appreciably from that made of stone aggregate. Though compressive strength of concrete in the normal range can be achieved satisfactorily, however, it is the durability properties like water permeability, creep, and shrinkage that has always been a concern for brick aggregate concrete. Water permeability is an important issue for concrete made from crushed clay bricks because brick aggregate is far more porous and hence permeable than granite and other natural stone aggregates [3]. There are a number of works that have been reported till today on properties of concrete made from brick aggregate [1-8]. However, none of these have extensively investigated water permeability of brick aggregate concrete except Debeib who has shown that it is possible to manufacture concrete containing crushed bricks (coarse and fine) with water permeability characteristics similar to those of natural aggregate concrete provided that the percentage of brick aggregate is limited to $25 \%$ and $50 \%$ for coarse and fine aggregates, respectively [5]. However, authors of this work feel that a systematic and comparative study of both natural stone and crushed clay brick aggregate concrete will assist in understanding the salient features of water permeability characteristics of brick aggregate concrete. This will also help designers and engineers using brick aggregate concrete in predicting the expected water permeability behavior. Outcome of this research would be a significant addition to the existing knowledge in this field because 
TABLE 1: Properties of brick and brick aggregate.

\begin{tabular}{lccccc}
\hline Brick type & Crushing strength $(\mathrm{MPa})$ & Specific gravity $(\mathrm{SSD})$ & Density $\left(\mathrm{Kg} / \mathrm{m}^{3}\right)$ & Water absorption $(\%)$ & LA abrasion value $(\%)$ \\
\hline 1 & 28.25 & 2.16 & 1450 & 9.8 & 39.25 \\
2 & 27.65 & 2.12 & 1422 & 1400 & 40.15 \\
3 & 18.30 & 2.10 & 1390 & 13.40 & 44.10 \\
4 & 17.25 & 2.06 & 1380 & 14.05 & 44.80 \\
5 & 14.85 & 2.02 & 1350 & 14.60 & 46.10 \\
6 & 13.95 & 1.97 & 17.90 & 49.50 \\
\hline
\end{tabular}

permeability is one of the main parameter responsible for concrete deterioration. Information regarding expected value of water permeability coefficient of brick aggregate concrete would help practicing engineers to design more durable and sustainable structures using brick aggregate concrete. This may also help to modify existing building codes on brick aggregate concrete in areas like clear cover over reinforcing bars of concrete as well as provisions for construction of water retaining structures using brick aggregate concrete. For this, an experimental program was conducted at Bangladesh University of Engineering and Technology, Dhaka, Bangladesh, to study the water permeability behavior of concrete made from crushed clay bricks. For this, six different brick and five different natural stone aggregates were selected. In the experimental program, concrete samples having three different compressive strengths were prepared from each of the natural stone and crushed clay brick aggregate. These samples were then subjected to water permeability testing using European standard AT 315 machine as per BS EN 12390-8: "Depth of Penetration of Water under Pressure" [9]. Test results were analyzed to examine the increase in water permeability associated with brick aggregate concrete compared to corresponding concrete made from natural stone aggregate. Several brick, brick aggregate, and concrete properties that include crushing strength of brick, water absorption of brick aggregate, water absorption, and porosity in hardened concrete were also measured. Influence of these properties on water permeability behavior of corresponding concrete was also investigated.

\section{Materials Used}

2.1. Cement. Ordinary Portland cement (Type 1) having 28day compressive strength of $46 \mathrm{MPa}$ as per ASTM C 150 [10] was used for preparation of all concrete samples. By using one type of cement the effect of varying the types of coarse aggregate in concrete was investigated.

2.2. Fine Aggregate. One type of natural coarse sand was used throughout the experimental work so as to keep the fine aggregate parameter constant. Sieve analysis was carried out in accordance with ASTM C136 [11]. The results of this analysis showed that the sand used fitted within the limits set out in ASTM C33 [12]. Unit weight of aggregates was also determined in accordance with ASTM C29/C29M [13] whereas water absorption and specific gravity of fine aggregate were found in accordance with ASTM C128 [14]. From these testing procedures, fineness modulus, unit weight, water absorption, and specific gravity of fine aggregate were found as $2.70,1630 \mathrm{Kg} / \mathrm{m}^{3}, 1.26 \%$, and 2.66 , respectively.

2.3. Clay Bricks. In this work, six different types of brick samples, numbered as 1 to 6 , were collected from different brick manufacturing factories. These factories use two types of widely used kiln in Bangladesh, that is, Bulls Trench Kiln and Fixed Chimney Kiln. Before these bricks were crushed down to aggregate, compressive (crushing) strength test was conducted according to ASTM C 67 [15]. Test results are reported in Table 1 which show that crushing strength of brick varied between 14 and $29 \mathrm{MPa}$. A large variation in crushing strength of brick was selected so that its effect on water permeability of concrete could be observed.

2.4. Brick and Stone Aggregate. Brick aggregate was produced by breaking down whole new bricks on a solid concrete surface using a hammer. Natural crushed sandstone boulders were used as stone aggregate. In this work, five different types of natural stone boulders were collected from diverse sources. For comparison purpose, bricks and stone boulders were crushed in a way so that they possess similar gradation and approximately same fineness modulus to negate the effect, if any, of size and shape on water permeability behavior of concrete. Additionally, it was also ensured that grading limits set out in ASTM C33 [12] is strictly maintained. Before preparing concrete, different properties of both brick and stone aggregates were measured. This includes water absorption and specific gravity as per ASTM C127 [16] and Los Angeles (LA) abrasion test as per ASTM C131 [17]. Test results are presented in Tables 1 and 2. Observation of these results show that stronger bricks have higher density and lower LA abrasion value. Additionally, all brick aggregates have lower density than that of crushed stone aggregate. Therefore, concrete of lower density may be achieved through use of brick aggregate. Water absorption of brick aggregate, on the other hand, was found to be several times higher than that of stone aggregate.

\section{Testing Scheme}

3.1. Mix Design and Mixing Method. The procedure for design of concrete mixes with normal aggregate can be used to design mixes using crushed brick aggregate [3]. In this work, mix design ratios for both stone and brick aggregate concrete with target compressive strength of 20.0, 30.0, and 40.0 MPa were evaluated from ACI method [18] with a water 
TABLE 2: Properties of natural stone aggregate.

\begin{tabular}{lcccc}
\hline Sl. number & Specific gravity $(\mathrm{SSD})$ & Density $\left(\mathrm{Kg} / \mathrm{m}^{3}\right)$ & Water absorption $(\%)$ & LA abrasion value $(\%)$ \\
\hline 1 & 2.63 & 1580 & 1.62 & 28.70 \\
2 & 2.20 & 1550 & 1.93 & 30.85 \\
3 & 2.69 & 1615 & 0.82 & 25.20 \\
4 & 2.67 & 1605 & 1.22 & 26.90 \\
5 & 2.64 & 1590 & 1.36 & 27.70 \\
\hline
\end{tabular}

cement ratio $(w / c)$ of $0.4,0.5$, and 0.6 , respectively, considering slump value in the range of 25 to $50 \mathrm{~mm}$. Required quantities for cement, water, coarse, and fine aggregate for all brick and stone aggregate are presented in Table 3 . Since water absorption of brick aggregate is much higher, it is recommended to soak the brick aggregates in water prior to adding to the concrete mixture $[2,3,6]$. Otherwise, a large part of water from mix design calculation will be soaked by the aggregate and will not be available to react with cement changing the water cement ratio. Hence, both stone and brick aggregate were soaked in water for $48 \mathrm{~h}$ and added to the mixture in a saturated surface dry condition. Water absorbed in the aggregate is in addition to the water requirement from mix design calculation as shown in Table 1. Fine aggregate was dried for $48 \mathrm{~h}$ in oven at $110^{\circ} \mathrm{C}$ and was allowed to cool to room temperature before adding to the mixture. Water requirement from mix design process was adjusted to consider effect of water absorption of fine aggregates. The aggregates, cement, and water were then combined and mixed in a machine mixer as per ASTM C 192 [19]. Slump tests were also conducted on fresh concrete as per ASTM C143 [20] and corresponding values are reported in Table 3. Concrete mixes for which slump value exceeded the design range of 25 to $50 \mathrm{~mm}$ were discarded and remixed.

For every set of concrete with particular target compressive strength, a total of three $300 \mathrm{~mm} \times 150 \mathrm{~mm}$ cylinder specimens and six $150 \mathrm{~mm} \times 150 \mathrm{~mm}$ cubes were cast. Cylinder specimens were subjected to compressive strength test as per ASTM C39 [21] maintaining a loading rate between 0.25 and $0.30 \mathrm{MPa} / \mathrm{sec}$. Three cube specimens were subjected to water permeability testing. The remaining three cubes were used to determine density, water absorption, and porosity in hardened concrete as per ASTM C642 [22].

3.2. Water Permeability Testing. European standard AT 315 apparatus was used to determine the water permeability of concrete according to EN 12390-8 [9]. The apparatus was connected to a normal air compressor capable of ensuring at least 5 bar compressed air continuously and equipped with dehumidifier and oil filter. Connection then was made to the laboratory water supply and to a drainage system. A specimen was subjected to test when its age was at least 28 days. For testing, the specimen was placed on the apparatus in such a manner that the water pressure act on the test area which actually is a $75 \mathrm{~mm}$ diameter area at the center of the bottom surface of the $150 \mathrm{~mm}$ by $150 \mathrm{~mm}$ cube. Water pressure of $(500 \pm 50) \mathrm{kPa}$ for $(72 \pm 2)$ hours was applied on this surface.

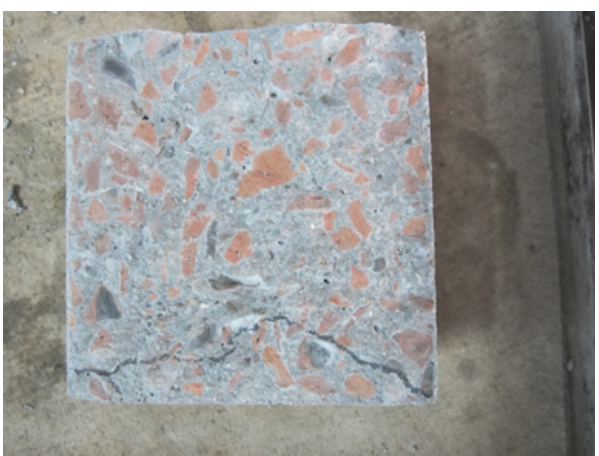

FIGURE 1: Water penetration area and penetration front in a brick aggregate concrete sample.

After the pressure had been applied for the specified time, the specimen was removed from the apparatus. The face on which the water pressure was applied was wiped to remove excess water. The specimen was then split in half, perpendicularly to the face on which the water pressure was applied. As soon as the split face has dried to such an extent that the water penetration front can be clearly seen, maximum depth of penetration under the test area was recorded and measured to the nearest millimeter. Figure 1 shows example of such penetration area and marked penetration front in a brick aggregate concrete sample.

The depth of water penetration inside the specimen can be converted to its equivalent coefficient of water permeability using Valenta's equation [23]:

$$
k=\frac{e^{2} v}{2 h t} \mathrm{~m} / \mathrm{sec}
$$

where $e$ is depth of penetration of concrete in meters, $h$ is hydraulic head in meters, $t$ is time under pressure in seconds, and $v$ is the fraction of the volume of concrete occupied by pores.

The value of $v$ represents discrete pores, such as air bubbles, which do not become filed with water except under pressure and can be calculated from the increase in the mass of concrete during the test.

\section{Results and Discussion}

4.1. Strength of Concrete, Water Absorption, and Porosity. Table 4 shows compressive strength test results on concrete samples prepared. As can be seen, compressive strength 
TABLE 3: Concrete mix proportions.

\begin{tabular}{|c|c|c|c|c|c|c|}
\hline \multirow[b]{2}{*}{ Aggr. types } & \multirow[b]{2}{*}{$w / c$} & \multicolumn{3}{|c|}{ Mix design } & \multirow[b]{2}{*}{$\begin{array}{l}\text { Water } \\
\mathrm{Kg} / \mathrm{m}^{3}\end{array}$} & \multirow[b]{2}{*}{ Slump (mm) } \\
\hline & & $\begin{array}{l}\text { Cement } \\
\mathrm{Kg} / \mathrm{m}^{3}\end{array}$ & $\begin{array}{c}\text { Fine aggregate } \\
\mathrm{Kg} / \mathrm{m}^{3}\end{array}$ & $\begin{array}{c}\text { Coarse aggregate } \\
\mathrm{Kg} / \mathrm{m}^{3}\end{array}$ & & \\
\hline \multirow{3}{*}{ Brick-1 } & 0.4 & 440 & 578 & 1000 & 176 & 30 \\
\hline & 0.5 & 360 & 634 & 1000 & 180 & 35 \\
\hline & 0.6 & 300 & 684 & 1000 & 180 & 45 \\
\hline \multirow{3}{*}{ Brick-2 } & 0.4 & 440 & 582 & 982 & 176 & 25 \\
\hline & 0.5 & 360 & 642 & 982 & 180 & 40 \\
\hline & 0.6 & 300 & 690 & 982 & 180 & 40 \\
\hline \multirow{3}{*}{ Brick-3 } & 0.4 & 440 & 592 & 966 & 176 & 30 \\
\hline & 0.5 & 360 & 648 & 966 & 180 & 45 \\
\hline & 0.6 & 300 & 698 & 966 & 180 & 45 \\
\hline \multirow{3}{*}{ Brick-4 } & 0.4 & 440 & 571 & 959 & 176 & 30 \\
\hline & 0.5 & 360 & 627 & 959 & 180 & 40 \\
\hline & 0.6 & 300 & 678 & 959 & 180 & 45 \\
\hline \multirow{3}{*}{ Brick-5 } & 0.4 & 440 & 549 & 952 & 176 & 35 \\
\hline & 0.5 & 360 & 606 & 952 & 180 & 45 \\
\hline & 0.6 & 300 & 656 & 952 & 180 & 50 \\
\hline \multirow{3}{*}{ Brick-6 } & 0.4 & 440 & 545 & 931 & 176 & 35 \\
\hline & 0.5 & 360 & 601 & 931 & 180 & 50 \\
\hline & 0.6 & 300 & 652 & 931 & 180 & 50 \\
\hline \multirow{3}{*}{ Stone-1 } & 0.4 & 440 & 722 & 1075 & 176 & 30 \\
\hline & 0.5 & 360 & 779 & 1075 & 180 & 35 \\
\hline & 0.6 & 300 & 829 & 1075 & 180 & 40 \\
\hline \multirow{3}{*}{ Stone-2 } & 0.4 & 440 & 743 & 1050 & 176 & 25 \\
\hline & 0.5 & 360 & 799 & 1050 & 180 & 35 \\
\hline & 0.6 & 300 & 849 & 1050 & 180 & 45 \\
\hline \multirow{3}{*}{ Stone-3 } & 0.4 & 440 & 698 & 1115 & 176 & 30 \\
\hline & 0.5 & 360 & 755 & 1115 & 180 & 35 \\
\hline & 0.6 & 300 & 805 & 1115 & 180 & 40 \\
\hline \multirow{3}{*}{ Stone-4 } & 0.4 & 440 & 705 & 1100 & 176 & 25 \\
\hline & 0.5 & 360 & 762 & 1100 & 180 & 35 \\
\hline & 0.6 & 300 & 812 & 1100 & 180 & 50 \\
\hline \multirow{3}{*}{ Stone-5 } & 0.4 & 440 & 715 & 1085 & 176 & 30 \\
\hline & 0.5 & 360 & 772 & 1085 & 180 & 30 \\
\hline & 0.6 & 300 & 820 & 1085 & 180 & 45 \\
\hline
\end{tabular}

achieved using stone aggregate concrete is fairly close and lies within $15 \%$ of the target compressive strength. On the other hand, achieved compressive strength using brick aggregate was far less than target strength. For example, for concrete of $40 \mathrm{MPa}$ target strength, the achieved compressive strength varied between 21 and $27.9 \mathrm{MPa}$, that is, about 30 to $47.5 \%$ lower than the target strength. For $20 \mathrm{MPa}$ concrete, the difference is, however, smaller. As can be seen in Table 4, clear difference is found in water absorption and porosity between brick and stone aggregate concrete. In the current testing scheme, water absorption and porosity for stone aggregate concrete were found to vary between 1.5 to $4 \%$ and 3.8 to $8.9 \%$, respectively, whereas, for brick aggregate concrete, water absorption and porosity varied between 5.9 to $9.9 \%$ and 7.6 to $15.8 \%$, respectively. That is, for equivalent compressive strength, water absorption and porosity in brick aggregate concrete were $60 \%$ to $80 \%$ higher. Similar trend was observed for brick aggregate concrete by other researchers $[5,8]$.

4.2. Compressive Strength of Concrete and Water Permeability. Water permeability of concrete made from natural stone and brick aggregate with respect to its compressive strength are presented in Figures 2 and 3, respectively. Coefficient of water permeability in this testing scheme for natural stone aggregate concrete was found to vary between 0.02 $\times 10^{-11}$ and $1.2 \times 10^{-11} \mathrm{~m} / \mathrm{s}$. These values are in agreement with available results on natural stone aggregate concrete [24-26]. For brick aggregate concrete, coefficient of water permeability varied between $2.2 \times 10^{-11}$ and $6 \times 10^{-11} \mathrm{~m} / \mathrm{s}$ for the range of compressive strength of concrete tested (16.7 


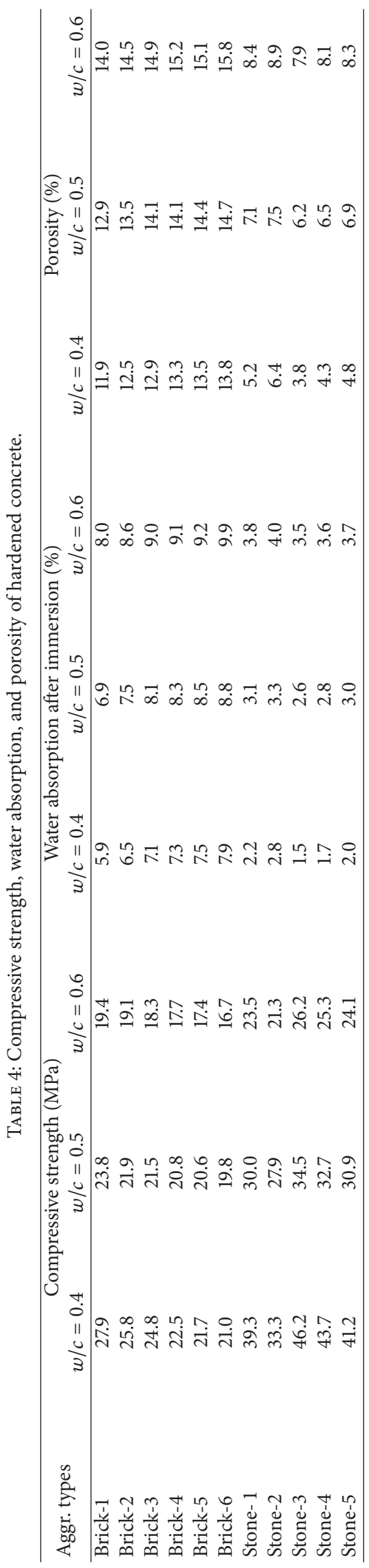




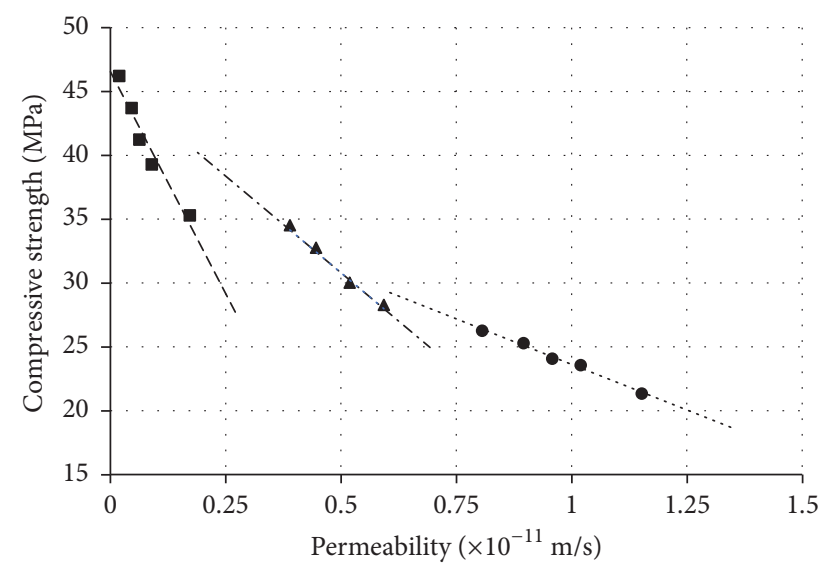

- $w / c=0.4$

ه $w / c=0.5$

- $w / c=0.6$

FIGURE 2: Water permeability coefficient with respect to compressive strength of stone aggregate concrete.

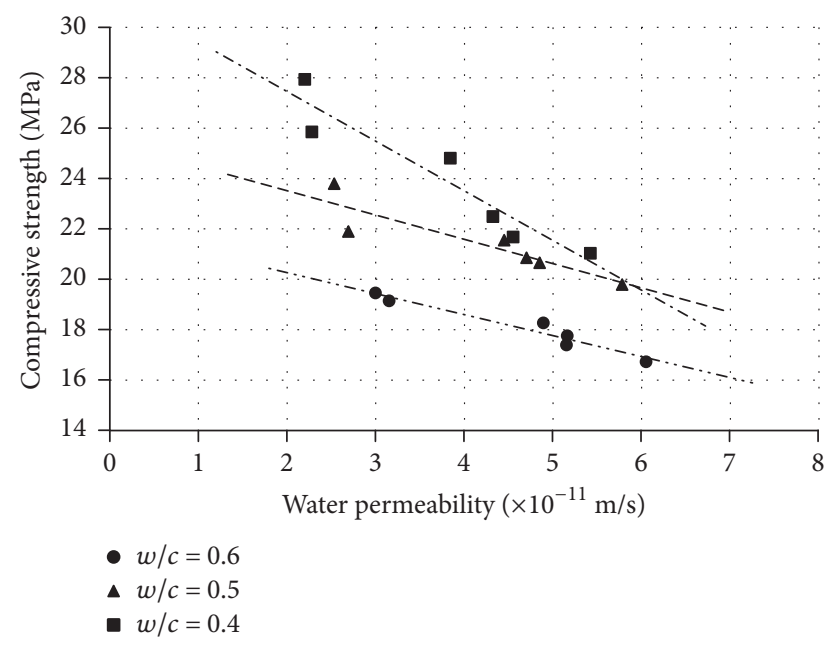

FIGURE 3: Water permeability coefficient with respect to compressive strength of brick aggregate concrete.

to $27.9 \mathrm{MPa}$ ). For a particular $w / c$ ratio, a well fitted straight line relationship was observed between coefficient of water permeability and compressive strength of stone aggregate concrete (Figure 2). Although not as fitting, an approximate straight line relationship between compressive strength and coefficient of water permeability for a specific $w / c$ ratio can still be identified for brick aggregate concrete (Figure 3). Observation of Figures 2 and 3 shows that, for both stone and brick aggregate concrete, increased $w / c$ ratio in the concrete mix results in corresponding increase in water permeability coefficient. Also, steeper curves suggest that percent increase in water permeability coefficient with respect to increase in compressive strength is more significant in stone aggregate concrete.

Next, coefficient of water permeability of brick aggregate concrete was compared to that of stone aggregate concrete of identical compressive strength. Linear variation

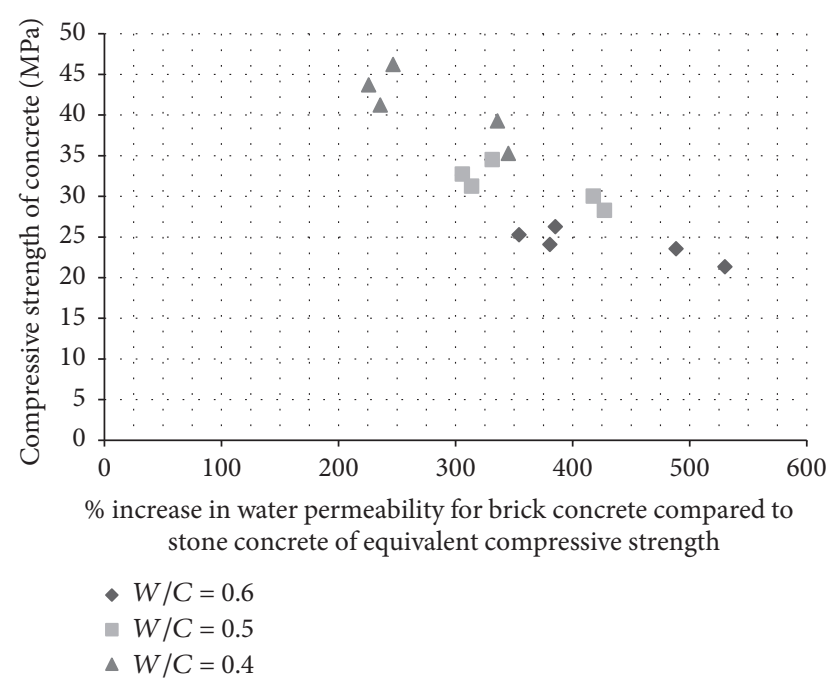

FIGURE 4: Comparative water permeability of brick and stone aggregate concrete.

was observed between coefficient of water permeability and compressive strength for both brick and stone aggregate concrete. Accordingly, coefficient of water permeability was evaluated by linear extrapolation of obtained test data in the range of compressive strength for which test data was not available. Comparison shows that water permeability coefficient of brick aggregate is several times higher than corresponding water permeability coefficient of stone aggregate concrete of identical compressive strength. Figure 4 shows such comparison where percent increase in water permeability for brick aggregate compared to that of stone aggregate concrete of identical compressive strength is plotted. Three data sets are plotted in this figure, one for each $w / c$ ratio, that is, $0.4,0.5$, and 0.6. For $w / c$ ratio of 0.4 and for concrete of equivalent compressive strength, coefficient of water permeability of brick aggregate concrete is 225 to $350 \%$ times higher. For $w / c$ ratio of 0.5 , increase in coefficient of water permeability of brick aggregate concrete ranges from 300 to $425 \%$, whereas, for $w / c$ ratio of 0.6 , coefficient of water permeability of brick aggregate concrete is 350 to $550 \%$ higher than that of stone aggregate concrete of identical compressive strength. Therefore, depending on compressive strength and $w / c$ ratio, water permeability of concrete with crushed clay brick as coarse aggregate is 225 to $550 \%$ higher than corresponding concrete with natural stone as coarse aggregate.

4.3. Water Permeability Related to Water Absorption and Porosity in Hardened Concrete. Both porosity and water absorption of brick aggregate concrete were found to be $60 \%$ to $80 \%$ higher (Table 4 ) making it much more pervious than natural stone aggregate concrete of equivalent strength. Porosity and water absorptions are indication of pores or voids in concrete through which water permeates. Therefore, increase in these parameters results in corresponding increase in water permeability [23]. Water permeability coefficient with respect to water absorption and porosity in hardened brick aggregate concrete are shown in Figures 5 


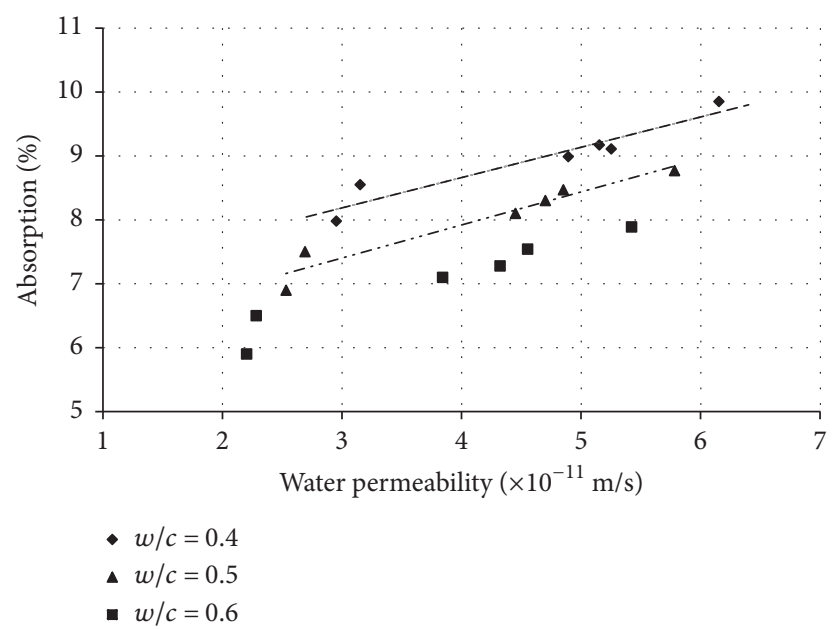

FIGURE 5: Water permeability coefficient with respect to water absorption of hardened concrete.

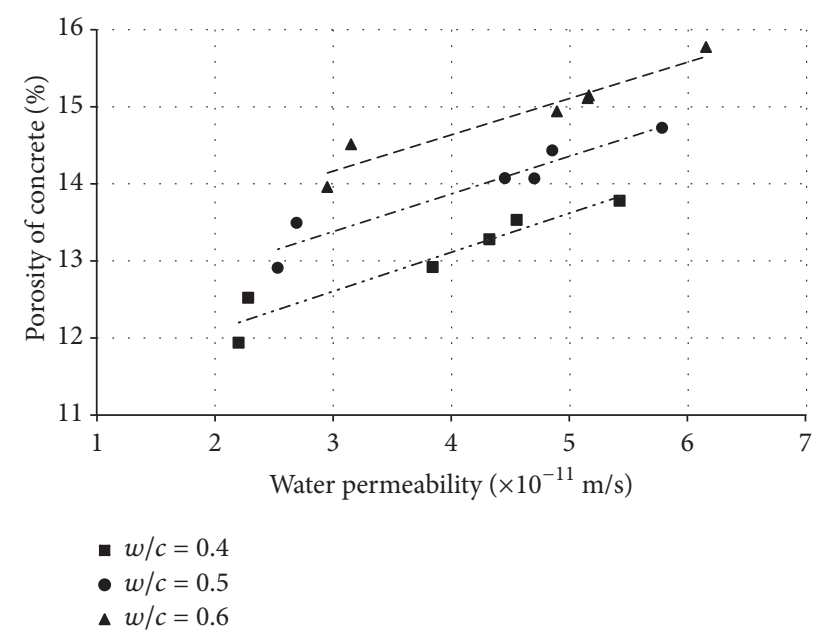

FIGURE 6: Water permeability coefficient with respect to porosity of hardened concrete.

and 6, respectively. Observation of these figures shows that a linear relationship exists between these parameters and water permeability coefficient for a specific $w / c$ ratio. Also, as can be seen, relatively flat slope of these straight lines indicates that water permeability coefficient of brick aggregate concrete is very much sensitive to these parameters. A similar linear behavior between porosity and water permeability was also observed for pervious concrete [26].

4.4. Water Permeability Related to Brick and Brick Aggregate Properties. Two important indicative properties of brick and brick aggregate are crushing strength of brick and water absorption of brick aggregate. Observation of Table 2 shows that bricks with higher compressive strength produce aggregates that have higher specific gravity and density as well as lower water absorption and LA abrasion values. Consequently, concrete produced from bricks with higher

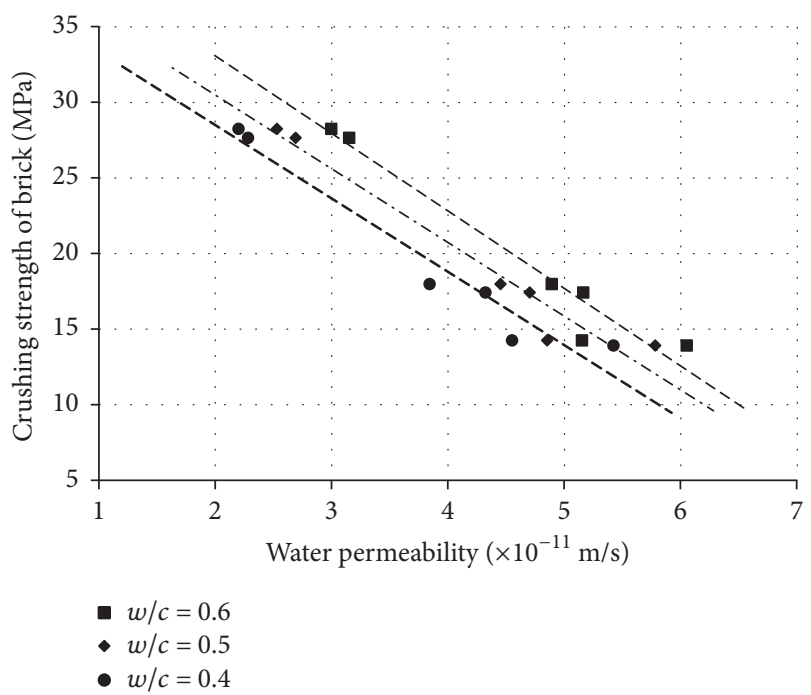

FIGURE 7: Water permeability with respect to crushing strength of brick.

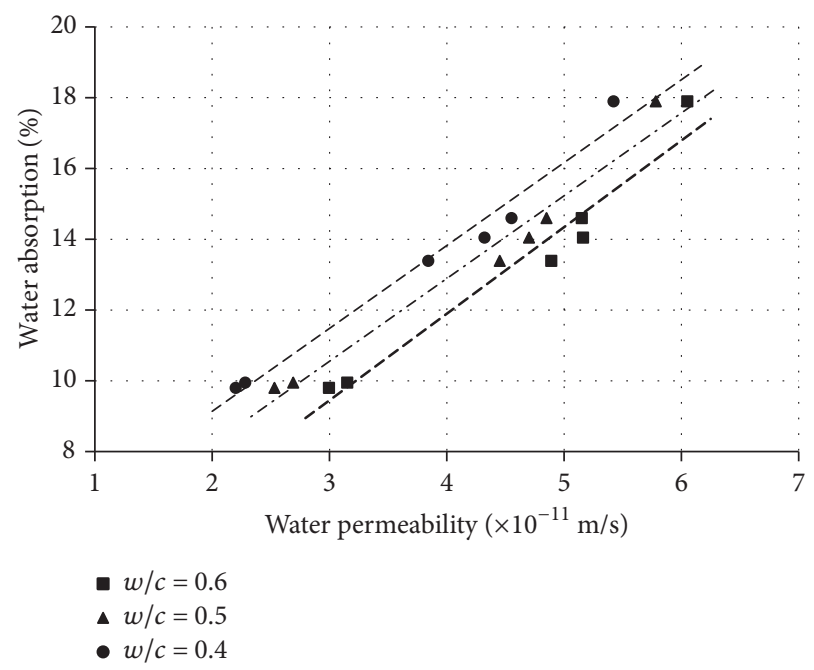

FIGURE 8: Water permeability with respect to water absorption of brick aggregate.

compressive strength has lower porosity (Table 4) and therefore it is less permeable. This is reflected in Figures 7 and 8, where crushing strength of brick and water absorption of brick aggregate is correlated with water permeability coefficient of concrete made from those aggregates, respectively. It may be seen from these figures that, for a specific $w / c$ ratio, an approximately linear relationship exists between water permeability of brick aggregate concrete and these two parameters. Understandably, increase in crushing strength of brick is associated with decrease in water permeability. On the other hand, increase in water absorption of brick aggregate results in corresponding increase in water permeability of concrete. As an example, if crushing strength of brick is increased from 15 to $25 \mathrm{MPa}$, water permeability of concrete is reduced from $4.75 \times 10^{-11} \mathrm{~m} / \mathrm{s}$ to $2.75 \times 10^{-11} \mathrm{~m} / \mathrm{s}$; that is, $66 \%$ increase in crushing strength of brick reduces water 
permeability of corresponding concrete by about $42 \%$. $1 \times$ $10^{-11} \mathrm{~m} / \mathrm{s}$ increase in coefficient of water permeability of brick aggregate concrete is observed when water absorption of brick aggregate is increased by 2 to $3 \%$, whereas, for $2 \%$ increase or decrease in water absorption of brick aggregate, permeability coefficient of corresponding concrete is found to increase or decrease, respectively, in a range of $0.8 \times 10^{-11} \mathrm{~m} / \mathrm{s}$ to $1.1 \times 10^{-11} \mathrm{~m} / \mathrm{s}$.

\section{Conclusion}

This paper examined the water permeability properties of crushed clay brick aggregate concrete and compared it with concrete made from natural stone aggregate. Based on experimental results found in this study, it can be concluded that coefficient of water permeability of brick aggregate concrete is always higher than natural stone aggregate concrete of equivalent strength. Depending on compressive strength and $w / c$ ratio, coefficient of water permeability of brick aggregate concrete may be $225 \%$ to $550 \%$ higher than that of stone aggregate concrete.

Additionally, following conclusions can be made based on the observations and experimental results in this investigation:

(i) For equivalent compressive strength, water absorption and porosity in hardened brick aggregate concrete are $60 \%$ to $80 \%$ higher compared to those in stone aggregate concrete.

(ii) For a specific $w / c$ ratio, compressive strength and water permeability of brick aggregate concrete are linearly related. Increase in strength shows a corresponding decrease in water permeability coefficient and vice versa.

(iii) For a specific $w / c$ ratio, linear relationship exists between water absorption and porosity in hardened brick aggregate concrete and its water permeability coefficient. Also, water permeability coefficient is very much sensitive to these parameters.

(iv) Coefficient of water permeability of brick aggregate concrete is linearly related to crushing strength of brick. $66 \%$ increase in crushing strength of brick reduces water permeability of corresponding concrete by about $42 \%$.

(v) Coefficient of water permeability in brick aggregate concrete is linearly related to water absorption of brick aggregate. For 2\% increase or decrease in water absorption of brick aggregate, permeability coefficient of corresponding concrete is found to increase or decrease, respectively, in a range of $0.8 \times 10^{-11} \mathrm{~m} / \mathrm{s}$ to $1.1 \times 10^{-11} \mathrm{~m} / \mathrm{s}$.

\section{Conflicts of Interest}

The authors declare that they have no conflicts of interest.

\section{References}

[1] M. A. Mansur, T. H. Wee, and L. S. Cheran, "Crushed bricks as coarse aggregate for concrete," ACI Materials Journal, vol. 96, no. 4, pp. 478-484, 1999.

[2] F. M. Khalaf and A. S. DeVenny, "Properties of new and recycled clay brick aggregates for use in concrete," Journal of Materials in Civil Engineering, vol. 17, no. 4, article 456, 2005.

[3] F. M. Khalaf, "Using crushed clay brick as coarse aggregate in concrete," Journal of Materials in Civil Engineering, vol. 18, no. 4, pp. 518-526, 2006.

[4] A. A. Akhataruzzaman and A. Hasnat, "Properties of concrete using crushed brick as aggregate," ACI Concrete International, vol. 5, pp. 58-63, 1983.

[5] F. Debieb and S. Kenai, "The use of coarse and fine crushed bricks as aggregate in concrete," Construction and Building Materials, vol. 22, no. 5, pp. 886-893, 2008.

[6] P. B. Cachim, "Mechanical properties of brick aggregate concrete," Construction and Building Materials, vol. 23, no. 3, pp. 1292-1297, 2009.

[7] S. I. Ahmad and S. Roy, "Creep behavior and its prediction for normal strength concrete made from crushed clay bricks as coarse aggregate," Journal of Materials in Civil Engineering, vol. 24, no. 3, pp. 308-314, 2012.

[8] M. Adamson, A. Razmjoo, and A. Poursaee, "Durability of concrete incorporating crushed brick as coarse aggregate," Construction and Building Materials, vol. 94, pp. 426-432, 2015.

[9] BSI, "Hardened concrete-part 8: depth of penetration of water under pressure," BS EN 12390-8, BSI, London, Uk, 2009.

[10] ASTM, "Specification for Portland cement," ASTM C 150, ASTM, West Conshohocken, Pa, USA, 2007.

[11] ASTM, "Standard test method for sieve analysis of fine aggregate," ASTM C 136, ASTM, West Conshohocken, Pa, USA, 2014.

[12] ASTM, "Standard specification for concrete aggregates," ASTM C 33, ASTM, West Conshohocken, Pa, USa, 2011.

[13] ASTM, "Standard test method for bulk density ("unit weight") and voids in aggregate," ASTM C29/C29M, ASTM, West Conshohocken, Pa, USA, 2009.

[14] ASTM, "Standard test method for density, relative density (specific gravity), and absorption of fine aggregate," ASTM C 128, ASTM, West Conshohocken, Pa, USA, 2015.

[15] ASTM, "Standard test methods for sampling and testing brick and structural clay tile," ASTM C67, ASTM, West Conshohocken, Pa, USA, 2014.

[16] ASTM, "Standard test method for density, relative density (specific gravity), and absorption of coarse aggregate," ASTM C 127, ASTM, West Conshohocken, Pa, USA, 2015.

[17] ASTM, "Standard test method for resistance to degradation of small-size coarse aggregate by abrasion and impact in the los angeles machine," ASTM C 131, ASTM, West Conshohocken, Pa, USA, 2014.

[18] American Concrete Institute (ACI), "Standard practice for selecting proportions for normal, heavyweight and mass concrete," ACI 211.1-91, American Concrete Institute, Famington Hills, Mich, USA, 2002.

[19] ASTM, "Standard practice for making and curing concrete test specimen in the laboratory," ASTM C 192/C192M, ASTM, West Conshohocken, Pa, USA, 2007.

[20] ASTM, "Standard test method for compressive strength of cylindrical concrete specimens," ASTM C 39, ASTM, West Conshohocken, Pa, USA, 2015. 
[21] ASTM, "Standard test method for slump of hydraulic cement concrete," ASTM C 143, ASTM, West Conshohocken, Pa, USA, 2015.

[22] ASTM, "Standard test method for density, absorption and voids in hardened concrete," ASTM C 642, ASTM, West Conshohocken, Pa, USA, 2013.

[23] O. Valenta, "The Permeability of Concrete in Aggressive Condition," in Proceedings of the 10th International Congress on Large Dams, pp. 103-117, 1970.

[24] A. M. Neville, Properties of Concrete, Longman Scientific and Technical, England, UK, 3rd edition, 1995.

[25] S. E. Hedegaard and T. C. Hansen, "Water permeability of fly ash concretes," Materials and Structures, vol. 25, no. 7, pp. 381-387, 1992.

[26] P. B. Bamforth, "The water permeability of concrete and its relationship with strength," Magazine of Concrete Research, vol. 43, no. 157, pp. 233-241, 1991. 

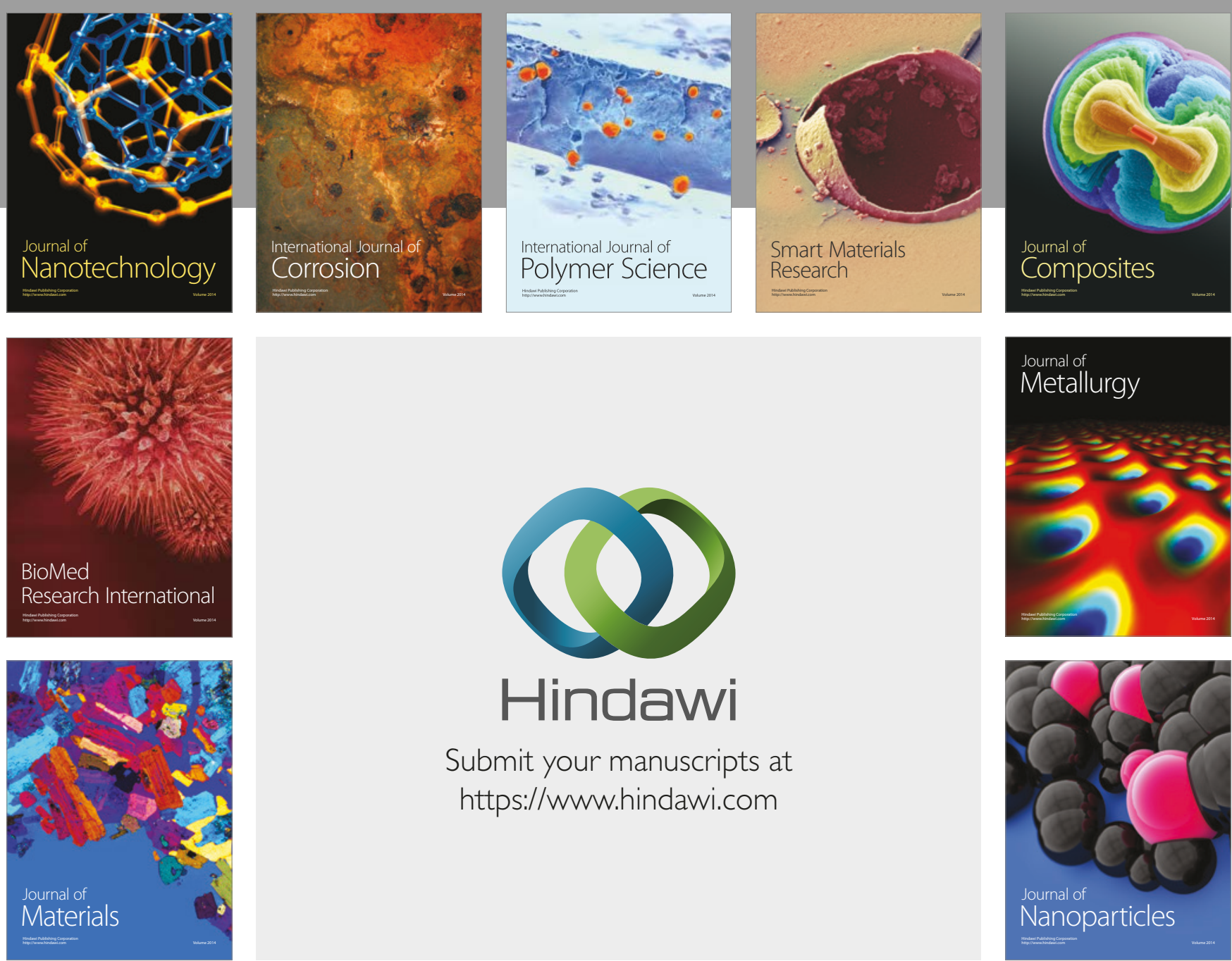

\section{Hindawi}

Submit your manuscripts at

https://www.hindawi.com
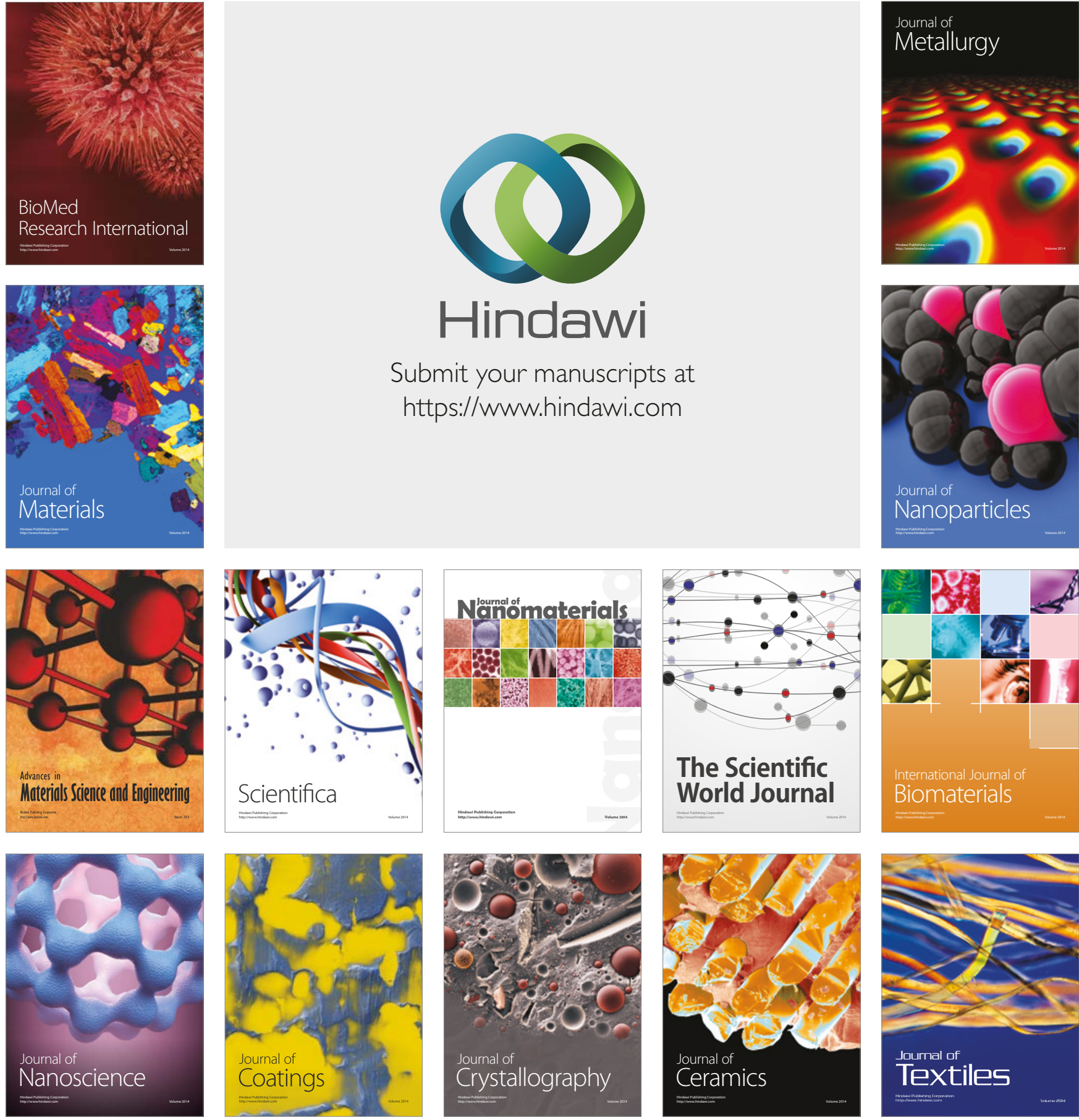

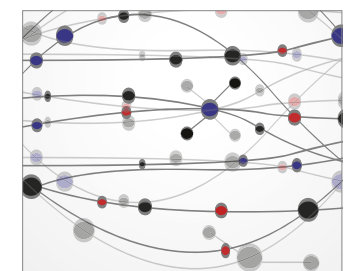

The Scientific World Journal
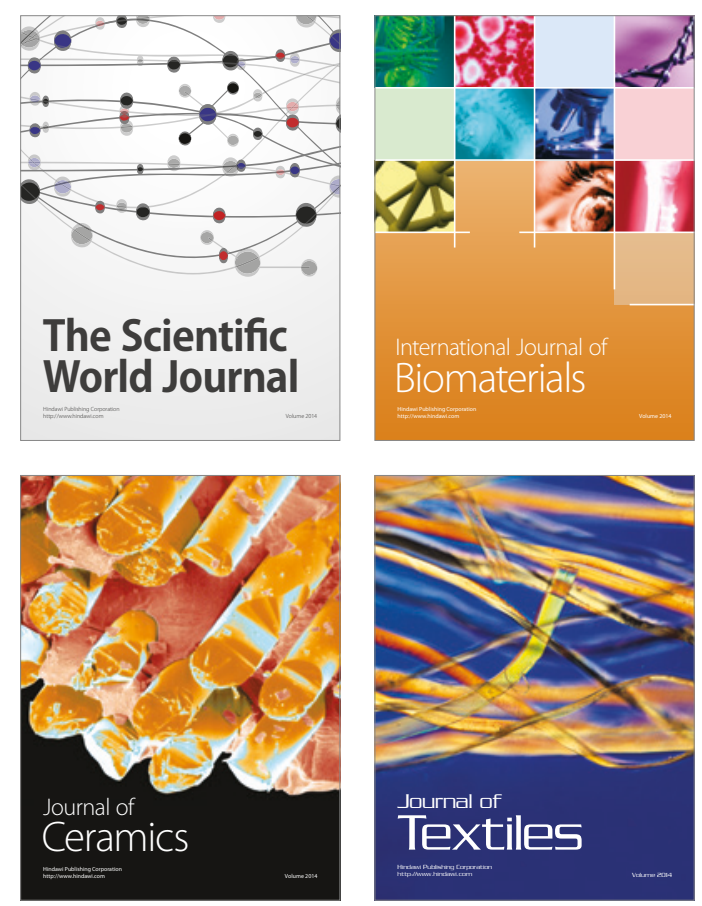